O. Pronevych, Dr. Sc. (Law), Prof.

Taras Shevchenko National University of Kyiv, Kyiv, Ukraine

\title{
THE INSTITUTE OF COUNSELOR IN THE DOMESTIC SYSTEM OF PUBLIC SERVICE: \\ THE STATE AND PROBLEMS OF LEGAL FIXING
}

The article is devoted to understanding the specifics of the social mission and the state of legal consolidation of the administrative legal personality of councilors in public authorities and local governments.

It is emphasized that the problem of selection of candidates for the positions of advisers to the heads of public authorities is the subject of lively discussion, as a rather controversial collective image of the adviser has formed in the public consciousness. This is due to his belonging to officials who hold a particularly responsible position and perform official duties in the presence of a high level of corruption risks. It is established that the commitment of candidates for advisers is carried out in the context of providing scientific support for the formation and implementation of public policy, implementation of best management practices, finding optimal management and legal algorithms for resolving conflicts, improving the quality of management decisions.

The urgent need to improve the domestic service legislation by adopting a special law on patronage service in order to unify the legal framework for the organization and operation of patronage services. First of all, it is necessary to normatively enshrine the right of specific public authorities to establish a patronage service, to provide an exhaustive list of patronage service positions for each of these bodies, to provide the right of equal access to patronage service, to introduce a single mechanism for selection and appointment of patronage service employees. professional achievements and personal business qualities, to differentiate their powers depending on the specifics of public authority of individual officials, which create patronage services.

There is also a need to specify the functions, main tasks and powers of advisers to heads of public authorities, articulation of basic qualification requirements for candidates for advisers, clear definition of legal bases of interaction of advisers with career civil servants and communication with civil society institutions, articulation of moral and ethical imperatives. official activity of advisers.

Keywords: public service, patronage service, adviser in state authorities and local self-government bodies, staff adviser, advisor on a voluntary basis.

Bulletin of Taras Shevchenko National University of Kyiv.

Legal Studies, 2021; 3 (118): 112-116

удк 343.237

DOI: https:doi.org/10.17721/1728-2195/2021/3.118-20
ISSN 1728-2195

(C) Taras Shevchenko National University of Kyiv,

Publishing center "Kyiv University", 2021

\section{ФОРМУВАННЯ УКРАЇНСЬКОЇ ПРАВОВОЇ ДОКТРИНИ ЩОДО КВАЛІФІКАЦІЇ КРИМІНАЛЬНИХ ПРАВОПОРУШЕНЬ, УЧИНЕНИХ ОРГАНІЗОВАНИМИ ЗЛОЧИННИМИ УГРУПОВАННЯМИ, У КОНТЕКСТІ ЗМІН КРИМІНАЛЬНОГО ЗАКОНОДАВСТВА}

Досліджено проблеми формування доктрини права щодо кваліфікації кримінальних правопорушень, учинених організованими злочинними угрупованнями, у зв'язку зі змінами кримінального законодавства України протягом 2020 2021 років. Здійснено системний аналіз і сформульовано основні висновки щодо впливу впровадженого інституту кримінальних проступків на кваліфікацію кримінальних правопорушень, учинених організованими злочинними угрупованнями. Висвітлено основні законодавчі зміни ст. 255 Кримінального кодексу України "Створення, керівництво злочинною спільнотою або злочинною організацією, а також участь у ній" відповідно до Закону України "Про внесення змін до деяких законодавчих актів України щодо відповідальності за злочини, учинені злочинною спільнотою". Також сформульовано основний зміст юридичних складів злочинів, специфічна частина яких передбачена частинами 1-5 cm. 255 Кримінального кодексу України; установлено обсяг і зміст понять "злочинна спільнота", "створення злочинної організації, керівництво такою організацією або ії структурними частинами", "участь у злочинній організації", "створення злочинної спільноти", "керівництво злочинною спільнотою". Наведено характеристику співвідношення юридичних складів злочинів, специфічна частина яких передбачена частинами 1-5 cm. 255 Кримінального кодексу України. Сформульовано основні правила кримінально-правової кваліфікації юридичних складів злочинів, специфічна частина яких передбачена частинами 1-5 cm. 255 Кримінального кодексу Украӥни. Указано на необхідність формування специфічного підходу до кримінально-правової кваліфікації кримінальних проступків, учинених організованою групою або злочинною організацією, оскільки ця проблема не вирішується в нормативній площині й нині є питанням практики застосування кримінального права та доктрини кримінального права.

Ключові слова: кримінальні проступки, злочинна спільнота, злочинна організація, організована група, створення злочинної спільноти, керівництво злочинною спільнотою, організовані злочинні угруповання.

\section{ВСТУП}

Актуальність проблематики. Статтею 1 Конституції України регламентовано: Україна є суверенна і незалежна, демократична, соціальна, правова держава. Одним із дестабілізуючих фракторів у побудові правової держави $€$ вчинення кримінальних правопорушень організованими злочинними угрупованнями. У зв'язку зі змінами кримінального законодавства протягом останніх двох років - суттєвих змін зазнали кримінальноправові норми, які безпосередньо чи опосередковано впливають на кваліфікацію кримінальних правопорушень, учинених організованими злочинними угрупованнями. Зауважимо, що більшість наукових публікацій, присвячених дослідженню організованих злочинних угруповань, опубліковано до набрання чинності відповідних змін у Кримінальному кодексі України (далі - КК).

3 урахуванням змін у кримінальному законодавстві кваліфікація кримінальних правопорушень, учинених організованими злочинними угрупованнями, потребує єдиних системних підходів, у першу чергу, на рівні судової правозастосовної практики. Формування української правової доктрини щодо кваліфікації кримінальних правопорушень, учинених організованими злочинними угрупованнями, є одним із суттєвих допоміжних орієнтирів у формуванні такої правозастосовної практики.

Метою статті $€$ формування окремих теоретичних підходів кваліфікації кримінальних правопорушень, учинених організованими злочинними угрупованнями. Для досягнення зазначеної мети визначено такі завдання: проаналізувати основні законодавчі зміни щодо кваліфікації кримінальних правопорушень, учинених організованими злочинними угрупованнями; дати оцінку основних підходів щодо вирішення проблем кваліфікації таких кримінальних правопорушень у законотворчій і правозастосовній практиці України.

Об'єктом дослідження є кримінальні правопорушення, учинені організованими злочинними угрупованнями; предметом дослідження - законодавчі положення, ос- 
новні правозастосовні та доктринальні підходи щодо кваліфікації кримінальних правопорушень, учинених організованими злочинними угрупованнями.

Для досягнення поставленої мети та визначених завдань основу дослідження склали такі методи: логіконормативний - для аналізу кримінального законодавства з питань кваліфрікації кримінальних правопорушень, учинених організованими злочинними угрупованнями; системного аналізу - при розгляді судової правозастосовної практики (у першу чергу, Верховного Суду та Верховного Суду України) кваліфікації кримінальних правопорушень, учинених організованими злочинними угрупованнями.

Аналіз останніх досліджень і публікацій. У зв'язку 3 істотними змінами кримінального законодавства України на час написання цього наукового дослідження відсутні нові доктринальні дослідження із зазначених питань, проте в ретроспективі зазначені проблемні питання $€$ одними з найактуальніших як у правовій доктрині, так і в правозастосовній практиці, оскільки за 30 років незалежності не було сформовано ефективних законодавчих положень, які б результативно попереджували кримінальні правопорушення, учинені організованими злочинними угрупованнями, чим, у першу чергу, й були обумовлені зміни у кримінальному законодавстві України за безпосередньою ініціативою Президента України.

\section{ВИКЛАД ОСНОВНОГО МАТЕРІАЛУ}

1. Вплив інституту "кримінальних проступків" на кваліфікацію кримінальних правопорушень, учинених організованими злочинними угрупованнями

У першу чергу, необхідно зазначити, що після набрання чинності 01.07.2020 р. Закону України "Про внесення змін до деяких законодавчих актів України щодо спрощення досудового розслідування окремих категорій кримінальних правопорушень" та впровадження інституту "кримінальних проступків" були внесені відповідні зміни й до законодавчої (нормативної) регламентації кримінальних правопорушень, учинених організованими злочинними угрупованнями. Зокрема, була змінена термінологія у статтях Кримінального кодексу України, яка регламентує основні форми кримінальних правопорушень, учинених організованими злочинними угрупованнями:

у ч. 3 ст. 28 КК слова "злочин", "злочину" і "злочинів" замінено відповідними словами "Кримінальне правопорушення", "кримінального правопорушення" і "кримінальних правопорушень";

у ч. 4 слова "злочин", "злочинної діяльності", "злочинних груп" замінено відповідно словами "кримінальне правопорушення", "кримінально протиправної діяльності", "кримінально протиправних груп".

Унаслідок цього були змінені поняття на "кримінальне правопорушення, вчинене організованою групою" (ч. 3 ст. 28 КК) та "кримінальне правопорушення, вчинене злочинною організацією" (ч. 4 ст. 28 КК).

У цілому ч. 3 та 4 ст. 28 КК були викладені в такій редакції:

"Ст. 3. Кримінальне правопорушення визнається вчиненим організованою групою, якщо в його готуванні або вчиненні брали участь декілька осіб (три і більше), які попередньо зорганізувалися у стійке об'єднання для вчинення цього та іншого (інших) кримінальних правопорушень, об'єднаних єдиним планом із розподілом функцій учасників групи, спрямованих на досягнення цього плану, відомого всім учасникам групи.

Ст. 4. Кримінальне правопорушення визнається вчиненим злочинною організацією, якщо воно скоєне стійким ієрархічним об'єднанням декількох осіб (п'ять і більше), члени якого або структурні частини якого за попередньою змовою зорганізувалися для спільної діяльності з метою безпосереднього вчинення тяжких або особливо тяжких злочинів учасниками цієї організації, або керівництва чи координації кримінально протиправної діяльності інших осіб, або забезпечення функціонування як самої злочинної організації, так і інших кримінально протиправних груп".

Аналогічних змін зазнала й редакція ст. 30 КК, в якій сформульовано основі правила кримінальної відповідальністі організаторів та учасників організованої групи чи злочинної організації:

"Ст. 30. Кримінальна відповідальність організаторів та учасників організованої групи чи злочинної організації

1. Організатор організованої групи чи злочинної організації підлягає кримінальній відповідальності за всі кримінальні правопорушення, вчинені організованою групою чи злочинною організацією, якщо вони охоплювалися його умислом.

2. Інші учасники організованої групи чи злочинної організації підлягають кримінальній відповідальності за кримінальні правопорушення, у підготовці або вчиненні яких вони брали участь, незалежно від тієї ролі, яку виконував у кримінальному правопорушенні кожен із них".

Відмітимо, що системний аналіз змін відповідно до зазначеного вище Закону дає можливість зробити однозначні висновки:

1. Кримінально-правовий зміст специфрічних ознак, які характеризують учинення кримінальних правопорушень організованою групою чи злочинною організацією, залишився незмінним;

2. Змістовно запровадження інституту кримінальних проступків не вплинуло на кваліфікацію кримінальних правопорушень, учинених організованими злочинними угрупованнями;

3. 3 урахуванням положень ст. 12 КК та статей Особливої частини КК, можливо зробити висновок, що на нормативному рівні кваліфікація таких кримінальних правопорушень залишилась незмінною. Так, при кваліфікації кримінальних правопорушень, учинених організованими злочинними угрупованнями, кваліфікуючі ознаки "вчинені організованою групою" або "вчинене членом організованої групи" передбачені лише в юридичних складах злочинів.

4. Окремо варто зауважити, що кримінальні проступки можуть бути вчинені й організованою групою чи злочинною організацією; при цьому відповідні кваліфікуючі ознаки в складах кримінальних проступків - відсутні. Наприклад, злочинна організація у своїй "діяльності" використовує завідомо підроблений документ. Відповідно до положень ч. 2 ст. 12 та санкції ч. 4 ст. 358 КК використання завідомо підробленого документа $€$ кримінальним проступком, специфічна частина якого передбачена ч. 4 ст. 358 КК.

5. Законодавчі спеціальні орієнтири (окрім загальних положень ст. 30 КК) щодо кваліфрікації кримінальних проступків, учинених організованими злочинними організаціями, відсутні.

Очевидно, що кримінальні проступки, учинені організованою групою або злочинною організацією, потребують специфічного підходу до кримінально-правової кваліфікації. Однак ця проблема не вирішується в нормативній площині й на сьогоднішній день $€$ питанням практики застосування кримінального права та доктрини кримінального права

2. Окремі доктринальні аспекти нових юридичних складів злочинів, специфічна частина яких передбачена ст. 255 КК "Створення, керівництво злочинною спільнотою або злочинною організацією, а також участь у ній"

Окремо необхідно звернути увагу, що 4 червня 2020 року Верховною Радою України за законодавчої ініціативи Президента України прийнято Закон України "Про внесення змін до деяких законодавчих актів України 
щодо відповідальності за злочини, вчинені злочинною спільнотою", який набрав чинності 27.06.2020 р. та відповідно до якого було змінено редакцію ст. 255 КК "Створення, керівництво злочинною спільнотою або злочинною організацією, а також участь у ній".

Так, зазначеним Законом регламентовано специфічну частину трьох основних юридичних складів злочинів (частини 1, 2 та 4 ст. 255 КК) та двох кваліфікованих юридичних складів злочинів.

Під час практичного застосування положень ст. 255 КК виникає ряд суттєвих питань, пов'язаних із кримінально-правовою кваліфікацією.

Перш за все, необхідно зазначити, що нормативне визначення поняття "злочинної організації" дає ч. 4 ст. 28 КК (визначення наведено раніше), тоді як законодавча дефініція злочинної спільноти передбачена ч. 4 ст. 255 КК. Так, згідно з ч. 4 ст. 255 КК злочинною спільнотою є об'єднання двох чи більше злочинних організацій. Таке законодавче визначення "злочинної спільноти" має низку проблем кваліфікації окремих кримінальноправових ситуацій.

Частиною 1 ст. 255 КК передбачено основний юридичний склад злочину за створення злочинної організації, а ч. 4 ст. 255 КК - за створення злочинної спільноти. Припустимо ситуацію, що суб'єктом створено спочатку одну злочинну організацію, а потім іншу, які в подальшому були об'єднані в злочинну спільноту.

Виникає запитання: чи потребує окремої кримінально-правової кваліфікації створення злочинних організацій, які в подальшому об'єднуються в злочинну спільноту; та чи взагалі відбувається "трансформація" злочинних організацій у злочинну спільноту; чи має значення для кримінально-правової кваліфікації, коли у суб'єкта виник умисел на створення злочинної спільноти - до створення злочинної організації чи після.

Убачається, що таку кримінально-правову ситуацію необхідно кваліфікувати за сукупністю злочинів, передбачених ч. 1 ст. 255 КК та ч. 4 ст. 255 КК за відсутності відповідних кваліфікуючих ознак; а "злочинну спільноту" необхідно визнати особливим злочинним угрупованням, передбаченим Особливою частиною КК. Причому на кримінально-правову кваліфікацію не впливає, коли у суб'єкта виник умисел на створення злочинної спільноти - до створення злочинної організації чи після. Варто також окремо зазначити, що об'єднання злочинних організацій як елемент об'єктивної сторони створення злочинної спільноти (ч. 4 ст. 255 КК) не передбачає створення злочинної організації.

Отже, зазначена кримінально-правова ситуація $\epsilon$ прямим проявом сукупності кримінальних правопорушень (злочинів) і відповідає положенням ст. 33 КК.

Такий підхід також ґрунтується на окремих, хоч і не прямих, правозастосовних орієнтирах (абз. 2 п. 1, абз. 3 п. 17 Постанови Пленуму Верховного Суду України від 23 грудня 2005 р. № 12 "Про практику розгляду судами кримінальних справ про злочини, вчинені стійкими злочинними об'єднаннями").

Також необхідно звернути увагу на те, що кримінально караним $€$ створення та керівництво злочинною спільнотою, тоді як участь у злочинній спільноті не регламентовано КК.

Убачається, що такий законодавчій підхід свідчить, зокрема про таке:

1. Участь у злочинній спільноті не утворює окремого юридичного складу злочину, а кримінально караними є лише створення та (або) керівництво злочинною спільнотою.

2. Участь у злочинній організації, яка $€$ частиною злочинної спільноти (тобто, участь у злочинній спільноті), містить лише склад злочину, специфічна частина якого передбачена ч. 2 ст. 255 КК.
3. У разі, якщо суб'єктом вчиняється діяння, яке містить специфічні ознаки певного виду (видів) співучасників, визначених ч. 3-5 ст. 27 КК, під час створення (керівництва) злочинної спільноти іншим суб'єктом, незалежно від того чи $є$ суб'єкт учасником злочинної організації, яка $€$ (буде) частиною злочинної спільноти, - суб'єкт визнається співучасником злочину, специфічна частина якого визначена ч. 4 ст. 255 КК, і підлягає кримінальній відповідальності відповідно до положень, регламентованих ст. 29 КК.

4. Створення злочинної спільноти не нівелює існування об'єднаних злочинних організацій, а відповідно й участь у них. Якби було б по-іншому і злочинна організація, яка разом 3 іншими злочинними організаціями об'єдналась у злочинну спільноту або увійшла до неї, втрачала свій колишній юридичний і організаційний статус, то декриміналізованими стали б окремі кримінально-правові ситуації. Наприклад, суб'єкт вступив та здійснює участь у вже існуючій злочинній спільноті. Очевидно, як було зазначено раніше, таку кримінальноправову ситуацію необхідно кваліфікувати за ч. 2 ст. 255 КК, як участь у злочинній організації.

Також необхідно зазначити, що для окремої злочинної організації може бути характерне поєднання кількох із зазначених в ч. 4 ст. 28 КК цілей їх утворення, а відповідно й функціонування (існування) таких злочинних організацій матиме самостійний, "індивідуальний" характер. Невиключними є ситуації, коли суб'єкт створив та здійснює керівництво декількома злочинними організаціями, об'єднаних однією спільною ціллю, яка відома виключно організатору таких злочинних організацій, а відповідно й злочинної спільноти.

Окремо необхідно звернути увагу, що законодавцем створення злочинної організації, керівництво такою організацією або її структурними частинами та участь у злочинній організації регламентовані не в межах одного юридичного складу злочину як альтернативні форми діяння (як, наприклад, це здійснено в юридичному складі бандитизму (ст. 257 КК)), а виділено в окремі юридичні склади злочинів: ч. 1 ст. 255 та ч. 2 ст. 255 КК.

Такий нормативний підхід зумовлює ряд питань, пов'язаних із кваліфікацією окремих фактичних ситуацій.

Наприклад, суб'єкт створив злочинну організацію, здійснює керівництво такою організацією та бере безпосередню участь у цій злочинній організації.

Під час кваліфікації такої ситуації виникають питання: змістовність діянь, передбачених ч. 1 та 2 ст. 255 КК; чи можна вважати керівництво злочинною організацією особливою формою участі в ній; та яким чином необхідно кваліфікувати дії суб'єкта у зазначеній фактичній ситуації?

Правозастосовним орієнтиром стосовно розуміння зазначених понять $є$ п. 4 Постанови Пленуму Верховного Суду України від 23 грудня 2005 р. № 12 "Про практику розгляду судами кримінальних справ про злочини, вчинені стійкими злочинними об'єднаннями" (далі постанова ПВСУ № 12).

Так, відповідно до п. 4 постанови ПВСУ № 12 "утворення (створення) організованої групи чи злочинної організації слід розуміти як сукупність дій з організації (формування, заснування) стійкого злочинного об'єднання для заняття злочинною діяльністю. Зазначені дії за своїм змістом близькі до дій з організації злочину і включають підшукання співучасників, об'єднання їхніх зусиль, детальний розподіл між ними обов'язків, складення плану, визначення способів його виконання. Проте основною метою організатора такої групи (організації) $€$ утворення стійкого об'єднання осіб для заняття злочинною діяльністю, забезпечення взаємозв'язку між діями всіх учасників останнього, упорядкування взаємодії його структурних частин".

Пунктом 5 постанови ПВСУ № 12 визначено, що: "Керування організованою групою або злочинною організацією полягає у вчиненні сукупності дій, спрямованих 
на управління їх функціонуванням як стійких об'єднань осіб (забезпечення існування, відповідного рівня організованості, дотримання загальних правил поведінки і дисципліни; вербування нових учасників, розподіл або перерозподіл між ними функціональних обов'язків; планування конкретних злочинів і злочинної діяльності в цілому; організація заходів щодо прикриття останньої; удосконалення структури об'єднання) та здійсненням ними злочинної діяльності (визначення ії̈ мети і напрямів, конкретних завдань об'єднання, його структурних частин або окремих учасників, координація їхніх дій; ініціювання здійснення певного виду злочинної діяльності чи вчинення конкретних злочинів тощо).

Зазначені дії організаційного характеру можуть здійснюватися у фрормі віддання наказів, розпоряджень, давання доручень, проведення інструктажів, прийняття звітів про виконання тих чи інших дій, застосування заходів впливу щодо учасників злочинного об'єднання за невиконання наказів і доручень або порушення встановлених у ньому правил поведінки".

Пунктом 13 постанови ПВСУ № 12 передбачено, що вступ особи до організованої групи чи злочинної організації (участь у ній) означає надання цією особою згоди на участь у такому об'єднанні за умови, що вона усвідомлювала фракт його існування і підтвердила певними діями реальність своїх намірів.

Зазначені правозастосовні положення не дають прямої відповіді, чи є керівництво злочинною організацією особливою (специфічною) фрормою участі в ній?

Якщо не визнавати керівництво злочинною організацією як особливу фрорму участі в ній - тоді наведену вище як приклад фактичну ситуацію необхідно кваліфрікувати за сукупністю злочинів, передбачених ч. 1 ст. 255 ; ч. 2 ст. 255 КК.

Проте доцільнішим видається підхід, що керування злочинною організацією $€$ особливою (специфічною) формою участі в ній, та в цьому конкретному прикладі ч. 1 ст. 255 КК $€$ спеціальною нормою відносно ч. 2 ст. 255 КК. Такий висновок можливо зробити, зокрема, шляхом системного аналізу зазначених вище пунктів постанови ПВСУ № 12 та положень ч. 1 та 2 ст. 255 КК.

Також постає питання, яким чином необхідно кваліфрікувати дії суб'єкта, який не був керівником злочинної організації, проте брав участь у первинному утворенні злочинної організації.

Очевидно, що в такому випадку орієнтиром $є$ положення, зміст якого був зазначений вище.

Отже, якщо під час кваліфрікації встановлено наявність сукупних дій, орієнтир щодо яких визначений п. 4 постанови ПВСУ № 12, то така конкретна фрактична ситуація відповідає юридичному складу злочину, специфічна частина якого передбачена ч. 1 ст. 255 КК (утворення злочинної організації). Якщо сукупність таких дій відсутня - відповідну фактичну ситуацію необхідно кваліфрікувати за ч. 2 ст. 255 КК у разі її реального створення.

Також необхідно звернути увагу на те, що оскільки ч. 1 ст. 255 КК та ч. 3 ст. 255 КК передбачено відповідальність за створення "злочинної організації" та "злочинної спільноти", а не за організаційну діяльність щодо їхнього створення, дії суб'єктів необхідно кваліфікувати як закінчений злочин лише у випадках, коли злочинну організацію або злочинну спільноту було реально створено. Організаційна ж діяльність, яка не дала такого результату, може розцінюватись як замах на створення злочинної організації або злочинної спільноти.

Незважаючи на те, що в ч. 4 ст. 255 КК розкривається зміст поняття "створення злочинної спільноти", законодавча дефініція має занадто узагальнений характер. У разі наповнення конкретним змістом поняття "створення злочинної спільноти" вважається доцільним використання опосередкованого правозастосовного орієнтиру - п. 4 постанови ПВСУ № 12.
Нормативне розуміння поняття "керівництво злочинною спільнотою" в КК - відсутнє. Опосередкованим правозастосовним орієнтиром під час визначення цього поняття може бути п. 5 постанови ПВСУ № 12.

\section{ВИСНОВКИ}

Підсумовуючи наведене щодо окремих особливостей нормативних тенденцій кваліфікації кримінальних правопорушень, учинених організованими злочинними угрупованнями, у зв'язку зі змінами кримінального законодавства протягом останніх двох років і формування на цій основі доктрини кримінального права, необхідно зазначити таке:

1. На законодавчому рівні впровадження інституту кримінальних проступків суттєво змістовно не змінило нічого.

2. Кваліфікуючі ознаки "вчинені організованою групою" або "вчинене членом організованої групи" передбачені лише в юридичних складах злочинів і відсутні на рівні нормативних складів кримінальних проступків.

3. Спеціальні законодавчі правила щодо кваліфрікації кримінальних проступків, учинених організованими злочинними угрупованнями - відсутні; кваліфікація відповідних кримінально-правових ситуацій здійснюється згідно із загальними нормами, регламентованими ст. 30 КК.

4. У законодавстві спостерігається посилення кримінальної відповідальності за вчинення кримінальних правопорушень організованими злочинними угрупованнями, зокрема, про це свідчать зміни, які були внесені в КК відповідно до Закону України "Про внесення змін до деяких законодавчих актів України щодо відповідальності за злочини, вчинені злочинною спільнотою" від 4 червня 2020 року.

5. На нормативному рівні законодавцем була впроваджена нова форма співучасті особливого роду "злочинна спільнота" (ч. 4 ст. 255 КК).

6. Окремі техніко-юридичні аспекти законодавчої регламентації потребують певних доопрацювань, а також вироблення уніфікованих підходів правозастосовної практики та доктрини кримінального права щодо розуміння юридичних складів злочинів, специфічна частина яких передбачена ч. 1-5 ст. 255 КК.

7. До формування нових підходів доктрини кримінального права та правозастосовної судової практики щодо кваліфікації кримінальних правопорушень (злочинів), специфрічна частина яких передбачена ч. 1-5 ст. 255 КК, опосередкованим орієнтиром $€$ положення Постанови Пленуму Верховного Суду України від 23 грудня 2005 р. № 12 "Про практику розгляду судами кримінальних справ про злочини, вчинені стійкими злочинними об'єднаннями".

Список використаних джерел

1. Кримінальний кодекс України : Закон України від 05.04.2001 № 2341-III. Дата оновлення : 23.04.2021. URL: https://zakon.rada.gov.ua/ laws/show/2341-14\#n1695 (дата звернення: 13.06.2021)

2. Постанова Пленуму Верховного Суду України "Про практику розгляду судами кримінальних справ про злочини, вчинені стійкими злочинними об'єднаннями" : Постанова від 23.12.2005 №12. Дата оновлення : 23.12.2005. URL: https://zakon.rada.gov.ua/laws/show/v0013700-05\#Text (дата звернення: 13.06.2021).

\section{References}

1. Kryminalnyi kodeks Ukrainy [The Criminal Code of Ukraine]: Zakon Ukrainy [Law of Ukraine] vid 5 kvitnia 2001 roku № 2341-III. URL: https://zakon.rada.gov.ua/laws/show/2341-14\#n1695 14 (accessed: 13.06.2021) (in Ukrainian).

2. Postanova Plenumu Verhovnogo Sudu Ukrainy "Pro praktuky rozgliady sydamu cruminalnuh sprav pro zlochunun, vchuneni stijkumu zlochunnumu objednanniamu" [Resolution of the Plenum of The Supreme Court of Ukraine "About the practice of consideration by courts of criminal cases on crimes committed by stable criminal associations"] : Postanova [Resolution] vid 23.12.2005 №12 URL: https://zakon.rada.gov.ua/laws/ show/v0013700-05\#Text (accessed: 13.06.2021).

Received: $15 / 06 / 2021$

1st revision: $10 / 07 / 2021$ Accepted: $30 / 07 / 2021$ 
D. Ptaschenko, Cand. Sc. (Law), Assist.

Taras Shevchenko National University of Kyiv, Kyiv, Ukraine

\section{FORMATION OF THE UKRAINIAN LEGAL DOCTRINE CONCERNING QUALIFICATION OF THE CRIMINAL OFFENSES COMMITTED BY THE ORGANIZED CRIMINAL GROUPS IN CONTEXT OF AMENDING CHANGES TO LEGISLATION ON CRIMINAL LAW}

The Article 1 of the Constitution of Ukraine regulates: Ukraine is a sovereign and independent, democratic, social, legal state. One of the destabilizing factors in building the rule of law is the commission of criminal offenses by organized criminal groups. Due to the changes in the criminal legislation during the last two years, the criminal law norms have undergone significant changes, which directly or indirectly affect the qualification of criminal offenses committed by organized criminal groups.

Given the changes in criminal law, the qualification of criminal offenses committed by organized criminal groups requires uniform systemic approaches, primarily at the level of judicial law enforcement practice. The formation of the Ukrainian legal doctrine on the qualification of criminal offenses committed by organized criminal groups is one of the significant auxiliary guidelines in the formation of such law enforcement practice.

To achieve this goal and the defined objectives, the following methods were applied in the study: logical and normative - for the analysis of criminal law on the qualification of criminal offenses committed by organized criminal groups; system analysis - when considering judicial law enforcement practice (first of all, the Supreme Court and the Supreme Court of Ukraine) of the qualification of criminal offenses committed by organized criminal groups.

The legislation strengthens criminal liability for criminal offenses by organized criminal groups, in particular, as evidenced by the amendments to the Criminal Code under the Law of Ukraine "On Amendments to Certain Legislative Acts of Ukraine on Liability for Crimes Committed by the Criminal Community" dated by the $4^{\text {th }}$ of June 2020.

Before the formation of new approaches to the doctrine of criminal law and law enforcement judicial practice on the qualification of criminal offenses (crimes), a specific part of which is provided by h.ch. 1-5 art. 255 of the Criminal Code, the indirect reference is the provision of the resolution of the Plenum of the Supreme Court of Ukraine of December 23, 2005 №12 "On the practice of consideration by courts of criminal cases on crimes committed by stable criminal groups."

Keywords: criminal offenses, criminal community, criminal organization, organized group, creation of a criminal community, leadership of a criminal community, organized criminal groups.

Bulletin of Taras Shevchenko National University of Kyiv. Legal Studies, 2021; 4 (118): 116-122

УДК 347.611

DOI: https:doi.org/10.17721/1728-2195/2021/3.118-21
ISSN 1728-2195

(C) Taras Shevchenko National University of Kyiv, Publishing center "Kyiv University", 2021

Л. І. Радченко, канд. юрид. наук, доц. Київський національний університет імені Тараса Шевченка, Київ, Україна ORCID ID: 0000-0002-3783-9489

\section{ПРАВОВЕ РЕГУЛЮВАННЯ РОЗІРВАННЯ ШЛЮБУ: ІСТОРИЧНИЙ РОЗВИТОК І СУЧАСНІ ЗАСАДИ}

Досліджено генезис правового регулювання порядку, умов і наслідків розірвання шлюбу в його історичному аспекmi, а також з огляду на сучасні засади регламентації сімейних відносин у праві ЄС та у законодавстві окремих іноземних держав, висвітлено новітні тендениії розвитку відносин у сфері розлучень й окреслено закономірності їхнього подальшого нормативного закріплення у сімейному праві України, сформульовано висновки і пропозиції, спрямовані на гармонізацію національного законодавства з правом ЄС.

Наголошено, що процедура розлучення, їі умови та правові наслідки регулюються законодавством різних держав по-різному. На зазначені відносини також суттєво впливають національні особливості, традиції, релізія та культура. Поширення сімейних правовідносин за межі однієї держави викликає необхідність застосування для регулювання таких відносин іноземного законодавства. Наслідком застосування права різних держав щодо підстав розлучення, процедури розірвання шлюбу, а також неоднакового визначення моменту його припинення, може стати виникнення відповідних колізій. Зазначене зумовлює практичне значення визнання наслідків розлучення, здійсненого за правом однієї держави в іноземних правопорядках.

Одним з основних принципів римського приватного права було дотримання принципу абсолютної свободи розлучення. Проте в імператорський період, та особливо з утвердженням християнства, були встановлені обмеження для розлучення. Підхід щодо суттєвого обмеження, та навіть заборони розлучення, упродовж тривалого часу спостерігався у праві європейських держав. Під впливом католицької церкви та християнської моралі рецепійоване римське право взагалі не допускало розлучення чи встановлювало обмеження та вагомі підстави для розлучення. Починаючи з другої половини XX cm., у багатьох країнах проведено реформи законодавства про розлучення, унаслідок яких розлучення стали більш лібералізованими.

Загальним колізійним принципом розірвання шлюбу визнається закон громадянства подружжя (більшість країн континентальної Європи) або закон місця проживання подружжя (Англія та ін.). Однак, Регламент ЄС $1259 / 2010$ передбачає інноваційні положення щодо обрання компетентного правопорядку у разі розлучення, закріплюючи можливість самостійного обрання подружжям застосовного права.

Ключові слова: шлюб, шлюбні відносини, розірвання шлюбу, розлучення, припинення шлюбу, право ЄС, сімейне право.

\section{ВСТУП}

Інститут шлюбу, так само як інститут сім'ї, $є$ базовою, основоположною сферою правової регламентації сімейного права будь-якої держави. Аналізу його правової природи, особливостей укладання і розірвання та зумовлених цими фактами правових наслідків завжди приділялась достатньо велика увага з боку юридичної науки. Поряд із цим, у сучасних умовах розвитку суспільства, зростання рівня міграції населення, посилення міжнародного культурного обміну та співробітництва спостерігається поступове переоцінювання, зміна основних засад регламентації цього традиційного правового інституту.
На регулювання відносин із розірвання шлюбу суттєво впливають національні особливості, традиції, релігія та культура. Поширення сімейних правовідносин за межі однієї держави пояснюється наявністю в цих відносинах правової категорії "іноземний елемент", що викликає необхідність застосування до таких відносин іноземного законодавства. Наслідком застосування законодавства різних держав може стати виникнення відповідних колізій.

Зазначене зумовлює актуальність розгляду проблематики розвитку правового регулювання умов, порядку та наслідків розірвання шлюбу як у його історичному контексті, так і з огляду на сучасні тенденції регламен- 